\title{
THE CABINET OF IRISH LITERATURE: \\ A HISTORICAL PERSPECTIVE ON IRISH ANTHOLOGIES*
}

MARGARET KELLEHER

\section{THE "CULTURE OF THE EXCERPT"}

AMONG the flurry of reviews and commentaries that followed the publication of volumes I to III of the Field Day Anthology of Irish Writing in 1991, those of most enduring interest moved beyond the heat of the moment to a more general reflection on the role of anthologies themselves. Francis Mulhern's 1993 essay, "A Nation, Yet Again" began, for example, with the cautionary pronouncement, by then all too evident, that "[a]nthologies are strategic weapons in literary politics." 1 Mulhern acknowledged that "authored texts of all kinds-poems, novels, plays, reviews, analyses-play more or less telling parts in a theatre of shifting alliances and antagonisms," but he argued for the special rhetorical force of anthologies in their "simulation of self evidence."

Here it is as it was: the very fact of re-presentation, flanked by equally selfattesting editorial learning, deters anyone so merely carping as a critic. And so, in principle, whole corpuses, genres, movements and periods can be "finished" - resolved, secured, perfected or, as the case may be, killed off. Anthological initiatives may be purely antiquarian, but more often they are not.

As early as 1984, Seamus Deane's first public mooting of the idea of "a comprehensive anthology" was strongly opposed by poet and critic Eiléan

* Research for this article was conducted during my year as John J. Burns Visiting Scholar at Boston College. I am also indebted to John Atteberry, Andrew Carpenter, Claire Connolly, Robin Lydenberg, Lucy McDiarmid, Kevin O'Neill, and Gemma Kelleher for their assistance.

I Francis Mulhern, 'A Nation, Yet Again,' review of Vols. I-IIl of the Ficld Day' Anthology of Irish Writing, in Radical Philosoplyy 65 (Autumn r993), 23.

\section{A HISTORICAL PERSPECTIVE ON IRISH ANTHOLOGIES}


Ní Chuilleanáin. ${ }^{2}$ And immediately after $F D A$ 's publication in 1991, she presented one of the most memorably discomfiting evaluations:

It is the trap of all anthologies: by "defining," that is excluding, they create a false inclusiveness in which the invisible exiles somehow do not count. Every claim to comprehensiveness is thus a devaluing of difference and so of the reality of a literary culture, past or present... . It is not the wrong choices or the predominance of pressure groups over individual talents, or the sexism-all of which are so evident-but the turning away of attention from the ground where the action is happening to the figures of the international talent-spotters half-visible behind their glassed-in gallery. ${ }^{3}$

Read from an international perspective, the Irish debate about anthologization and its omissions may appear a very late entry into the AngloAmerican canon wars of the $1980 \mathrm{~s}$. On the other hand, the above reflections anticipate increasing recent attention to the anthology as a distinct literary genre, attention evident in works such as Barbara Benedict's Making the Modern Reader: Cultural Mediation in Early Modern Literary Anthologies (1996), Anne Ferry's Tradition and the Individual Poem: An Inquiry into Anthologies (2001), and Leah Price's The Anthology and the Rise of the Novel: From Richardson to George Eliot (2000). Overall, these investigations share an investment in the significance of the anthology-viewed most positively by Ferry who claims that its influence can be discerned "in virtually all the revisionary moments in literary history since the sixteenth century." 4

The study of anthologies recently entered into a rare level of media coverage of a young academic's career; in November 2002 a staff writer for the Los Angeles Times reported a "bidding war" between Harvard and UCLA over Leah Price, a scholar of Victorian literature. Sardonically, the reporter remarked that her specializations included "the role played bygasp-abridgements in the role of the novel. ${ }^{n 5}$ Yet Price's engaging study of the anthology's role in the rise of the novel-a genre that, as she shows, forms a test case "within a culture of the excerpt"-is explicitly informed by the current economics of publishing. She notes that because much of

2 See Eiléan Ni Chuilleanáin, review of Heroic Styles: The Tradition of an Idea by Seamus Deane in Cyphers 21 (1984), 50-\$2.

3 Ni Chuilleanáin, review of FDA I-III, in Cyphers 35 (1992), 52.

4 Anne Ferry, Tradition and the Individual Poem: An Inquiry into Anthologies (Stanford, Calif.: Stanford University Press, 2001), 6.

5 See Rebecea Trounson, "Top Universities Shoot the Moon in Pursuit of New Stars," Los Angeles Times, 17 November 2002.

A HISTORICAL PERSPECTIVE ON IRISH ANTHOLOGIES 
today's market is dependent on college survey courses, among the volumes of poetry published, only anthologies can hope for mass-market success. Such economics, declares Price, have made "poem" nearly synonymous with "anthology-piece." Echoing John Guillory's influential shift in emphasis from the "evaluative" to the "institutional" as the key factor determining canon-formation, ${ }^{7}$ she insists that anthologies do more than inform us of who's in, who's out: "They determine not simply who gets published or what gets read, but who reads and how." The function of anthologies as powerful mediating forces between individual readers and literary culture, or as "talent-spotters" in Ní Chuilleanáin's less polite term, leads Barbara Benedict to similar conclusions. Until the early eighteenth century at least, she observes, anthologies, miscellanies, and collections sold cultural literacy-and an accompanying social power-to readers by offering them an accessible means of mastering the current literary culture. 9

But to what ends such social power is directed is a question less easily resolved by these investigations. Leah Price notes how the anthology becomes a less conservative form if regarded not simply as a "container," but as a self sufficient "genre." 10 Benedict is more ambivalent, identifying what she calls the "contrary impulses" of the form: "to consolidate a canon and to debunk it, to interpret literary meanings for an audience, and to refuse this role."11 Benedict argues, moreover, that such seemingly contradictory motivations continue to control current anthologies, an argument that helps unpack the self-positioning performed by the Irish anthology editor Seamus Deane in his "General Introduction" to FDA 1-IIIitself an object-lesson in sinuous prose:

There is no attempt here to establish a canon. Instead, what we show is an example of the way in which canons are established and the degree to

6 Leah Price, The Anthology and the Rise of the Novel: From Richardson to George Eliot (Cambridge: Cambridge University Press, 2000), 2-5.

7 Central to Guillory's work is his following thesis: "An individual's judgment that a work is great does nothing in itself to preserve that work, unless that judgrnent is made in a certain institutional context, a setting in which it is possible to insure the reproduction of the work, its continual reintroduction to generations of readers"; see his Cultural Capital: the Problem of Literary Canon Formation (Chicago: University of Chicago Press, 1993), 28.

8 Price, The Antbology and the Rise of the Novel, 3.

9 Barbara Benedict, Making the Modern Reader: Cultural Mediation in Early Modern Lit. erary Anthologies (Princeton, N.J.: Princeton University Press, 1996), 211.

10 Price, The Anthology and the Rise of the Novel, 3 .

11 Benedict, Making the Modern Reader, 221.

\section{A HISTORICAL PERSPECTIVE ON IRISH ANTHOLOGIES}


which they operate as systems of ratification and authority.... Therefore, we consider ourselves to be engaged in an act of definition, rather than in a definitive action. ${ }^{12}$

\section{THE CABINET OF IRISH LITERATURE (1879-1880): ITS PUBLISHING HISTORY}

Deane's General Introduction to FDA I-III begins with an assertion justifying the ambitious project:

One reason for producing an anthology of Irish writing on this scale is, quite simply, that it has never been done before. Of course anthologies of Irish literature have been published, the most notable being The Cabinet of Irish Literature, edited by Charles Read in four volumes in 1879 , and its enlarged version co-edited with Katharine Tynan Hinkson, in 1903, closely followed in rorr by Justin McCarthy's ten-volume compilation, alphabetically arranged, Irish Literature. ${ }^{13}$

Deane also emphasizes the distinctive character of the Field Day Anthology when contrasted with its predecessors: "its much wider time-span, embracing 1,500 years," and its avoidance of "the narrow sense of the word "literature." The $F D A$, according to its editor, includes an unparalleled range of writing-such as political speeches, pamphlets and analyses-in order to tell its story of Irish culture. In actuality, Deane seriously overstates the "foundational" status of his anthology, an overstatement that carries with it an elision of earlier anthologies and of their significance. Even in his one sentence description, the volumes of Irish Literature are incorrectly dated (they first appeared in 1904), and the complexities of editorial responsibility for both anthologies that he mentions are greatly simplified. Yet such glancing allusions to previous anthologies are far from unusual-typically made by researchers who either have used these projects much more than they acknowledge, or should have used them more. Anthologies are generally cited because of their individual contents; very rarely are they conceived of or discussed as distinct literary work, and as highly effective instruments in the construction and preservation of tradition.

The Cabinet of Irish Literature (1879-1880), a major four-volume anthology of Irish writing, rich in the variety and range of its selections, is the

12 Seamus Deane, "General Introduction" to The Field Day Anthology of Irish Writing, 3 vols. (Derry and London: Field Day and Faber and Faber, 1991), xix.

13 Deane, "General Introduction," xix.

A FISTORICAL PERSPECTIVE ON IRISH ANTHOLOGIES 
focus of this article. Its publishing history is complex and little known: first published by Blackie and Son, Glasgow, the first three volumes were credited as the work of Charles Anderson Read and the fourth to T.P. O'Connor. ${ }^{14}$ The publisher's announcement, reprinted in the preliminary material to volume I ( 1879 ), explained the origins of the project in the following terms:

The conviction has been gradually growing that the literary wealth of Ireland is being scattered broadcast, while yet no standard Work can be procured in which the genius, the fire, the pathos, the humour and the eloquence of Irish literature are adequately represented.

The aim of the Publishers is to supply this want, and from the wide acquaintance of the Editor with the literature of his native land, it is hoped that a Work will be produced thoroughly NATIONAL in character, interesting to readers in general, and valuable as a book of reference. It will consist of a treasury of selections, accompanied by biographical notices of their authors. Besides the Poets, Dramatists, Novelists, and Historians, the Orators will be fully represented in it, among whom such men as Burke, Flood, Grattan, Curmn, Sheridan, Plunkett, $\mathrm{O}^{\prime}$ Connell, Whiteside, Butt and Cairns stand out conspicuously... . The specimens selected will be arranged chronologically from the year 1600 to the present time, and taken together with the biographical notices, will present a comprehensive historical view of Irish literature; so that the work as a whole will supply in this convenient collected form an infinitely varied store of literary matter that cannot fail to afford both instruction and amusement to readers of all classes.

In preparing the Biographical Sketches the Editor has throughout consulted the best authorities, and endeavoured to place before the reader the authors and orators, their writings and speeches, from a literary point of view, entirely unbiassed by prejudice, political or religious.

Significantly, this prospectus also announced the publication of the work in two forms: "in fourteen parts, super-royal 8vo, at 2s. each," and also in "four volumes," priced at 8s. $6 d$. each.

Blackie and Son ${ }^{15}$ the Cabinet's Glasgow publisher, with offices in London, Dublin, Belfast and Edinburgh, was founded in 1809 and was one

14 This first edition, in which the title pages of volumes I and II are dated 1879 , and vol. umes III and IV dated 1880 , is very rare; a copy is held by the National Library, Dublin, and also in the Joseph McGarrity collection, Villanova University.

15 After 1890 , Blackie became a public limited company and amalgamated with the printing business W.G. Blackie and Co, to form Blackic and Sons Ltd.

\section{A HISTORICAL PERSPECTIVE ON IRISH ANTHOLOGIES}


of the pioneers of "the numbers trade." In this system, books were issued periodically and by subscription in sections or "numbers," bound in limp paper covers, and sold at modest prices. Publishers' agents or canvassers enlisted subscribers by visiting them at home or their places of work. Thus large and expensive books, many of which were dictionaries or encyclopedias, could be purchased in parts or "numbers" by a wide audience. Until 1870 , the majority of Blackie publications were sold through subscriptions, one of the most famous being the Casquet of Literary Gems published in sixty-four numbers between 1827 and 1829 . After 1873 , the firm moved into educational publishing and, from 1881 onward, began publication of the children's books for which it is now chiefly remembered. Yet subscription publishing continued beyond the 1870 s and experienced a temporary revival in fortunes with the publication of a revised edition of the highly successful Imperial Dictionary (1847-1850; 1883) and a new and retitled edition of the Casquet of Literature $(1871-1874)$, edited by Charles Gibbon.

The archive of Blackie and Son, held at University of Glasgow, contains stock records for the serial issue of the Cabinet, which was produced at more or less monthly intervals between October 1878 and April 1880. ${ }^{16}$ Probably a large proportion of this printed stock was in turn used for the four-volume edition, for which it was bound in cloth boards. ${ }^{17}$ The records show that by $1890,18,000$ copies of the first number had been issued; 16,000 of the second; 15,000 of the third; declining to 11,000 for the final number. ${ }^{18}$ The size of these editions is small in comparison to other Blackie serials; for example, by April 1883, 73,750 of the first number of the Casquet of Literature had been issued. On the other hand, given its specific focus on Irish literature, the Cabinet sales were respectable and, viewed

16 See Blackie Stock Edition Book, Ref. UGD 61.4.1.2, Glasgow University Archive. My deep thanks to the staff of Archive Services, Thurso Street, University of Glasgow, for their assistance during my visit.

17 Although the ledger entry for stock of the Cabinet of Irish Literature is divided into fourteen columns, one for each part, from February 1880 onward sixteen figures are entered in each line; this suggests that sixteen parts in total were printed and many of them in turn bound in groups of four, for the four-volume edition. Given the piecemeal release of the fourvolume edition (evidenced both by the title page dates and by contemporary reviews), the anthology may well have also been published by subscription. No other figures for the $\mathrm{Cab}$. inet exist in the Blackie archive, and it is impossible to ascertain what proportion of the listed stock was released in the two-shilling numbers. To my knowledge, none of these survive.

18 From 1890 to 1900, when stock entries end for the Cabinet, between 2,500 and 3,000 further copies of each number were produced.

A HISTORICAL PERSPECTIVE ON IRISH ANTHOIOGIES 
proportionately, were much more consistent than the Casquet whose thirty-sixth and final number had, by April 1883, generated only 23,000 copies.

The frequent reprinting of the four-volume format-with at least five reissues in Great Britain by $1897-$ further attests to the existence of a considerable market for the anthology. The Cabinet was also co-published in the United States in 1883 and 1884 by Blackie and Samuel L. Hall, New York, and was published solely in the United States as late as 1903 by P. Murphy and Son, New York. In addition, as the library of Joseph McGarrity illustrates, prominent Irish-Americans may have purchased the earlier British editions. The volumes were an expensive purchase: many poetry anthologies of the time cost between one and five shillings, cheap reprints series of novels cost in the region of five shillings a volume, whereas railway library editions cost $2 s 6 d$ or less. ${ }^{19}$ The British edition of the Cabinet, which cost thirty-four shillings for its four volumes, was slightly more expensive than the price of a three-decker novel of the period, selling for a total of one and a half guineas or 3is. $6 d$ and accessible to most readers only through circulating libraries.

The production values of the edition were lavish and were widely praised by reviewers. In the words of its publisher, the Cabinet was bound in "cloth elegant with edges in burnished olivine," with green cloth boards elaborately decorated in black and gilt, and celtic motifs embellishing the front, back, and spine. Each volume comprised 336 pages, with double columns per page, and each contained eight mesochrome portraits (tinted lithographs), an especially popular feature. The tall size of these volumes-ten by seven inches-distinguished them from smaller, more portable anthologies. ${ }^{20}$ Given its appearance and price, many of the Cab. inet's reviewers commented on the edition's worthiness "to occupy a place in every library in the country." 21 Its accessibility to individual purchasers was clearly limited, but the prestige attached to ownership all the higher; the Freeman's Journal, for example, ended its review by remarking that ' $[t]$ he four volumes as they are turned out are worthy of any library, and

19 See Sabine Haas, "Victorian Poetry Anthologies: Their Role and Success in the Nineteenth-Century Book Market," Publishing History 17 (1985), 51-64, 52-53.

20 Thus, as Benedict has observed in relation to the function of eighteenth-century anthologies, "[b]y expanding into series identically sized, organized, and bound like the volumes of a gentleman's library in a country house, these later anthologies present literature as a symbol of gentility"; see Making the Modern Reader, 17.

21 See Limerick Cbronicle, 7 March 1882, 4.

A HISTORICAL PERSPECTIVE ON IRISH ANTHOLOGIES 
will adorn any drawing-room table. ${ }^{22}$ Over a hundred years later, copies are preserved in the United States in the private collections of figures such as Joseph McGarrity (Villanova University, Philadelphia), Judge Henry O'Brien (Burns Library, Boston College), and Captain Francis O'Neill (University of Notre Dame)-their pages usually unmarked and in pristine condition.

\section{THE CABINETS EDITORS: THE READS AND O'CONNOR}

The first three volumes of the 1879-80 edition of the Cabinet were published as the work of Charles $A$. Read, with the fourth and final volume edited by T.P. O'Connor. Read and O'Connor belonged to an increasingly confident Irish-born and London-based professional class, men and women who came to particular prominence in the fields of publishing (Read and Edmund Downey, for example) and journalism (T.P. O'Connor, Justin McCarthy, F.H. O'Donnell, John Cashel Hoey, Elizabeth Owens Blackburne Casey). Like so many of their contemporaries involved with literature, journalism, and publishing, Read and $O^{\prime}$ Connor played a significant role in Irish cultural politics of the late nineteenth century. In relation to that confederation of disparate political interests known as the Home Rule movement, for example, their work helped consolidate the separatist rhetoric that, according to Roy Foster, the Irish Parliamentary Party emphasized "when it suited them."23

In January 1878 , Read died of consumption, at the age of thirty-six, just months before the first number was published. According to O'Connor's preface to the first edition, dated April 1880, Read had prepared virtually all of the first three volumes, which were "carried through the press" by Mrs. Read, who also supplemented the volumes with additional contributions. O'Connor himself claimed responsibility only for the fourth volume. ${ }^{24}$ Poignantly, Read is the subject of the very last entry in volume four, which includes a poem that he composed for his wife just before his death, and a short biographical sketch authored by his fellow anthologist Charles Gibbon. Read was born, according to Gibbons, in Kilsella House, near Sligo, and the family later moved to Hilltown, near Newry, where his father worked as a schoolmaster and where the young Read, "under the

22 Freeman's Joumal, 19 June $1882,6$.

23 Roy Foster, Modern Ireland: 1600-1972 (London: Penguin, 1989 [1988]), 399.

24 This preface was first included in volume 4 of the $1879-80$ edition and is signed "London, April r880"; in all subsequent editions it was included in Volume $\mathrm{x}$.

A HISTORICAL PERSPECTIVE ON IRISH ANTHOLOGIES 
instruction of his mother, acquired a knowledge of Irish."25 (Read would provide his own translation from the Irish in the Cabinet's first selected text: Geoffrey Keating's poem "Óm sceol ar Árdmfhagh Fáil"-tmanslated as "Thoughts on Innisfail."26) Following failure in business, Read and his wife moved in 1863 to London where he worked as an editor in the publishing house of James Henderson, the proprietor of various popular periodicals including the Weekly Budget and the publisher of a sixpenny pocket library series. ${ }^{27}$ Less well documented is the role of Mrs. Read, herself an author whose works included a series of Irish folktales entitled When Malachi Wore the Collar of Gold (1886).

Writing in the context of early nineteenth-century European nationalism, Julia Wright notes the significant part literary anthologies played in circulating and activating a presumed national culture. ${ }^{28}$ In his prefatory remarks, T.P. O'Connor, Read's successor as the Cabinet's editor, shows a related awareness of the key role the anthology had in developing a national historical, social, and cultural awareness. "Such a book," he wrote, is

primarily necessary for the purpose of enabling the literary history of Ireland to be traced in a systematic manner; and not the liternry history only, but also the historical and social development of the people ... most Irishmen, moreover, have felt the desire for a work in which they could readily find access to the gems of literary effort which rest in their memory, and would be gladly seen again.

O'Connor's remarks also acknowledge the personal dimensions of a literature that simultaneously is made to constitute a public history; or, as Leah Price points out, "in the process of recognizing commonplaces...

25 The Cabinet of Irish Literature Selections from the Works of the Chief Poets, Orators and Prose Writers of Ireland (London, Glasgow, Edinburgh and Dublin: Blackie, 1879-80), IV, 330. All further page references are given in parentheses.

26 Cabinet of Irish Literature, $1,2$.

27 In addition, before commencing work on the Cabinet in 1876, Read authored at least nine novels, some with Irish settings, and a number of which were published by Henderson. He also produced a series of stories from the ancient classics for young readers. In the anthology, he is also identified as a Fellow of the Royal Historical Society, a notable honor given his age.

28 Julia Wright, "The Order of Time': Nationalism and Literary Anthologies, 1774-1831," Papers on Language and Literature 33:4 (Fall 1997), 339-65. As Wright remarks, "such a nationalism could not be widely activated unless the presumed national culture was circulated among the groups which it was supposed to embrace in order for them to recog. nize their involvement" (339).

A HISTORICAL PERSPECTIVE ON IRISH ANTHOLOGIES 
readers learn to recognize themselves within a common culture. ${ }^{29}$ The commonplace may, however, all too soon degenerate into the hackneyed, and the preface's conclusion, acknowledging this danger, reveals the tensions of O'Connor's contemporary situation: "Finally, it has been the constant aim to avoid the quotation of anything that has become hackneyed or that could wound the feelings or offend the taste of any class or creed."

Journalist and politician T.P. O'Connor, later famous as the founder of The Star and The Sun newspapers, was, when involved with the anthology, at an early and relatively impoverished stage of his career. Having moved to London in 1870 , he was employed intermittently by newspapers, including the Daily Telegraph and the New York Herald. In 1880 O'Connor was elected MP for Galway and from I885 was MP for the Scotland division of Liverpool-the only member of the Irish Parliamentary Party to sit for an English constituency. Correspondence from the time shows that

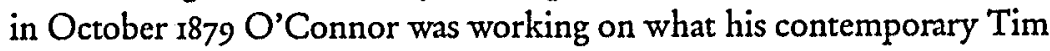
Healy termed the "Gallery of Irish Writers,"30 but otherwise frustratingly little information exists about his editing of the anthology. O'Connor's autobiography, Memoirs of an Old Parliamentarian, for example, allocates half a sentence to the Cabinet, in contrast to its detailed attention to his lucrative and controversial biography of Disraeli, Lord Beaconsfield (1879), a work that brought him a useful notoriety before the impending Galway election. O'Connor recalls the anthology only in the context of his difficulty in securing the candidate's fee for the Galway nomination. "And with that cheque for $£_{95}$ in my pocket and a few pounds more from another publisher-I was editing at the time a book on Ireland for Messrs Blackie-I reached Euston at 8.45 and shortly after noon the next day I was in Galway and beginning my candidature." 31

Yet O'Connor's work on the Cabinet coincided with a significant crossroads in his political career. He was a popular member of the radical wing of the English Liberal party, according to William O'Brien, "one of the rising hopes of that Party."32 Although O'Connor was approached in 1879 to stand for the Dewsbury constituency in northern England and was considered a likely Liberal nominee for Derry, he was a controversial figure. Warned by F.H. O'Donnell that O'Connor was an "extreme Radical,"

29 Price, The Anthology and the Rise of the Novel, 104.

30 T.M. Healy, Letters and Leaders of My Day, 2 vols. (London: Butterworth, c.1928), I, 76. See also Hamilton Fyfe, T.P. O'Connor (London: Allen and Unwin, 1934).

31 T.P. O'Connor, Memoirs of an Old Parliamentarian, 2 vols. (London: Benn 1929), I, 37.

32 William O'Brien, Recollections (London: Macmillan, 1905), 244-45.

A HISTORICAL PERSPECTIVE ON IRISH ANTHOLOGIES 
"politically a Liberal above all," and a supporter of the atheist Charles Bradlaugh, Parnell nevertheless invited $\mathrm{O}^{\prime}$ Connor to stand for Galway City as a Nationalist and pledged Home Ruler. ${ }^{33}$ And, as late as March 1880, the Freeman's Journal remarked that it knew nothing of this Galway candidate, other than that he was "stated to be a journalist." ${ }^{34}$ Within months, however, he was a sitting MP, member of the Home Rule party, and soon after a widely known anthology editor with established cultural credentials.

Read and $O^{\prime}$ Connor both viewed The Cabinet of Irish Literature as a means of cultural repossession. According to Gibbon, not only did Read believe the anthology long overdue, but one of his "chief aims was to show how many of those authors who hold a first place in 'English literature' belonged to his country" (IV, 331). In his preface to the anthology, O'Connor displays a similar cultural nationalism. Acknowledging the successful role of figures such as O'Donovan, O'Curry, and Petrie in the recent interest in "Celtic research" and early Irish literature, $O^{\prime}$ Connor declares that the volumes making up the anthology have been prompted both by the Irishman's neglect of his own literature and by "rhe astonishing ignorance" displayed by the English about Irish literature:

There are few Irishmen, I venture to think, who have any conception of the number of well-known literary names which belong to Ireland. Accustomed to read and hear of many writers as belonging to English literature, we are liable to forget their connection with Ireland; and thus many eminent authors pass for being English who were born on Irish soil.

With such an assertion, $O^{\prime}$ Connor sounds a familiar note, for concerns that Irish writers had been absorbed into an English market and tradition preoccupied post-Union commentaries; his description of authors who "pass for being English" is an interesting variation on that theme. And a century later, what Deane has termed "the power of the English canonical tradition to absorb a great deal of writing that, from a different point of view, can be reclaimed for the Irish tradition" continues to motivate anthologies of Irish writing. ${ }^{35}$

33 Writing in 1910, with O'Connor's later opposition to Parnell lodged in public mem. ory, O'Donnell would remark snidely that his conversation with Parnell "may have deprived the Liberal party of an avowed and trusty member, if I did deprive them"; see FH. O'Donnell, A History of the Irish Parliamentary Party (London: Longmans, Green and Co., 1910), 393-94.

34 Freeman's Journal, 29 March 1880, s; cited by O'Donnell, History, 394.

35 Deane, "General Introduction," xix.

A HISTORICAL PERSPECTIVE ON IRISH ANTHOLOGIES 


\section{THE CABINETS "CONTAINING SPACE"}

The word "cabinet" was a common term for anthologies from at least the middle of the seventeenth century-as in $A$ Cabinet of Spiritual Jewels (1657) with its connotations of a repository for safe custody and display of valuables. Its use in the nineteenth century, for example in Cabinet of General Knowledge (1803) or The Cabinet of Poetry (1808), underscores the intellectual value of the anthology's contents and the social prestige of ownership. Such use also suggests more domestic connotations than alternative terms such as "treasury" or Blackie's own "casquet." Anne Ferry explains the fre'quency with which the titles of anthologies draw attention to themselves as containing spaces; such titles, unlike those of authorial or editorial collections, signal their spatial dimension by "wording that both sets apart and links together container and contained." The very use of terms such as "cabinet" or "casket," rather than "book" or "works," she maintains, calls attention to the anthology as a book "not wholly identifiable with or wholly describable by its contents." ${ }^{36}$ (Most recently, in the context of Irish anthologies, the editors of FDAIV-V chose the term "sampler" to describe their work, presumably for its gendered history as well as for the dual connotation of older artifact and new technological form.)

Overall, the Cabinet of Irish Literature is arranged chronologically, a recent development-in comparison with an ordering, for example, by genre, theme, or school-in the history of anthologies. Julia Wright dates the origins of the chronological national anthology to the end of the eighteenth century, suggesting that this evolutionary model facilitated the "construction of a national, cultural history that had a clear origin and then a genealogically defined, continuous trajectory." 37 In their general structure, the Cabinet volumes construct a clear genealogy. Volume I commences with the work of Geoffrey Keating (excerpted from translations) in the early seventeenth century and proceeds to the late eighteenth century, ending with selections from Charlotte Brooke. Volume II covers the late eighteenth and early nineteenth centuries, beginning with the works of politician and orator Henry Flood and ending with those of the poet and translator Richard Henry Wilde. Volume III, spanning the first half of the nineteenth century, begins with the works of Thomas Moore and ends with those of John Mitchel; and Volume IV commences with the work of Charles Lever and concludes with that of Charles Read. Yet the ordering

36 Ferry, Tradition and the Individual Poem, 24.

37 See Wright, "The Order of Time," 344-48.

A HISTORICAL PERSPECTIVE ON IRISH ANTHOLOGIES 
of material within the volumes provides a much more jagged chronology: the selections are organized loosely in chronological order, in some cases, but not always, according to the dates of birth of the authors. ${ }^{38}$ Moreover, a collection that begins with the translated work of Geoffrey Keating, Gerald Nugent, Teige Macdaire, Owen Ward and Michael O'Clery, and then moves to the writings of Richard Stanihurst and Ludovick Barry has, from its opening pages, more than one trajectory to trace, be it in linguistic or socio-cultural terms. ${ }^{39}$

Read and O'Connor's inclusion of orators in an anthology seemingly of "literature" was-as is clear from the publisher's prospectus-a strong selling-point for the series. The selections from Flood, Grattan, O'Connell, Whiteside, and Butr underline the performative character of much of the writings of the period and undoubtedly invoked strong interest from the Cabinet's first audience. Read's selections from $O^{\prime}$ Connell appear particularly pointed; his excerpt from O'Connell's December 1812 speech on "Catholic Ascendency," for example, includes the Liberator's assurance that "there is no event which I should consider more fatal to the liberties of Ireland than what they have called a Catholic ascendency." The excerpt from the June 1813 speech on "Repeal of the Union" opens with O'Connell's refutation of the charge that he sought a separation between Ireland and England: "The charge is false; it is to use a modern quotation, as 'false as hell!'” (III, 269-85). Nor are oratorical selections confined to those with a specifically Irish context. O'Connor's choice from contemporary figures includes, for example, speeches by the Co. Down born and Trinity College educated Earl Cairns (whom F.H. O'Donnell later described as "the pride of Protestant Ulster" ${ }^{20}$ ) on Indian affairs, including an 1876 speech in defense of the title "Empress of India" (IV, 201-6).

In all four volumes, the criteria upon which the "Irishness" of a selection is determined are markedly broad. The last volume features an excerpt from the Indian mutiny novel Seeta (1872) by Liverpool-born Colonel Meadows Taylor-both because Taylor's farher and grandfather were Irish and because he had spent the last years of his life in the family house in Dublin (IV, 84-90). Yorkshire-born Annie Keary is represented by a scene from her novel Castle Daly (1875), judged to be "probably the best Irish

38 This inconsistency may have resulted from a desire to accommodate the choice of portmits, originally two per part-as well as from the exigencies of serial production.

39 A later anthology, lrish Literature, 10 vols. $(1904)$ would deal with this issue by arranging entries alphabetically by name of author.

40 O'Donnell, History of the Irish Parliamentary Party, 1, wn.

\section{A HISTORICAL PERSPECTIVE ON IRISH ANTHOLOGIES}


story of the present generation." Although Keary spent a total of some two weeks in Ireland, she is described as "Irish in heart and sympathies, as well as in descent" (IV, 132). In volume I, William Congreve-whose nationality constitutes a fault-line for anthologies of Irish writing ${ }^{41}$ - is well represented by extracts both from his poetry and drama. In addition, the Cabinet's editorial commentary carefully corrects previous biographical errors that located Congreve's birthplace in Yorkshire rather than Ireland (I, 149-56).

Many of the selections made by Read and O'Connor stand up remarkably well to the test of time. In the case of individual figures, even the shortest excerpts are well chosen, often illustrating a range of writing from the span of an author's career. For the most part both editors successfully handle tasks that have bedeviled anthologists: how to select from longer works such as novels and plays, how to negotiate between the "best" and the most characteristic features of a writer's work. The excerpts themselves and the accompanying biographical notes illustrate how the Cabinet played a role in the making (and unmaking) of literary reputations. For example, in contrast to the opprobrium heaped upon Sydney Owenson (Lady Morgan) by some late-nineteenth-century commentators, Read performs a conscious act of rehabilitation; although noting that Owenson failed to admire Daniel O'Connell, he praises her support of emancipation. Moreover, he asserts that her Irish novels "full of sympathy for the ancient race and their sufferings, attracted attention and raised inquiry in quarters where an eloquent speech or political pamphlet would have had no success" (III, 27). In addition, O'Connor's Volume IV, by including selections from the work of over seventy living authors, helped shape contemporary literary reputations. Given the exclusion of living authors from other anthologies-most notably from the early editions of Palgrave's Golden Treasury-O'Connor's editorial decision was both significant and sometimes contentious, leading early reviewers, like their twentieth- and twenty-first-century counterparts, to take issue with wrongfully perceived exclusions and inclusions.

From the publisher's advertisement that preceded The Cabinet of Irish Literature to O'Connor's preface that marked its completion, the project was overtly characterized by an editorial policy seeking to avoid "prejudice, political or religious" that "could wound the feelings or offend the taste of any class or creed." Contemporary reviewers approved such a pol-

4I In the Field Day Anthology, for example, Congreve is expressly excluded (see I, xix).

A HISTORICAL PERSPECTIVE ON IRISH ANTHOLOGIES 
icy. The conservative unionist paper Dublin Daily Express, for example, praised the anthology's "manifest effort ... to avoid all political and theologic bias. ${ }^{n 2}$ The Freeman's Journal-addressing itself to a very different political constituency-commented on the Cabinet's "excellent discretion" exercised "to keep clear of controversial and irritating subjects," its "rigid exclusion of sectarianism in the extracts" (itself a revealing phrase), and its "most unsectarian comprehension of authors." ${ }^{33}$ The conservative Limer. ick Chronicle's reviewer listed the unlikely pairings that resulted as a result of such an inclusive religious and political editorial policy: "We meet with the names of Archbishop Usher and Cardinal Wiseman, Archbishop Trench and Archbishop MacHale, Father Burke and William Archer Butler, Robert Emmet and Lord Castlereagh, John Mitchel and Chief Justice Whiteside." ${ }^{\text {44 }}$

The selections themselves are, however, often more politically robust than such a seemingly non-contentious policy might suggest. In the commentaries that precede the extracts, the editor is at pains to present potentially contentious figures as unanimously acclaimed. Thus O'Connor's volume presents Catholic Archbishop M'Hale as having procured "considerable respect even among those who most strongly oppose him" (IV, 14). Similarly, "Irishmen of whatever creed cannot but feel gratified" by the acclaim secured by Dr. William Connor Magee, a "most popular preacher in the Church of England" and "one of the greatest pulpit orators of the day" (IV, 99). O'Connor judges the "remarkable" career of Conservative politician Hugh Cairns-who strongly opposed the disestablishment of the Church of Ireland-as "an unbroken series of triumphs" and asserts that "even those who have no love for his politics cannor deny that those triumphs have been legitimately earned" (IV, 201). Of the Earl of Dufferin, recently Governor-General of Canada, O'Connor maintains that "[t]he Orangeman and the Roman Catholic, the Conservative and Radical alike" are seen to artest to his influence (IV, 245). "Speranza" (Jane Francesca Elgee Wilde), the author of fiery political verse, appears in the Cabinet as a devotee of the "noble theme of national regeneration" (IV, 80). (But the politi$\mathrm{cal}$ activist and journalist Frances Power Cobbe fares less well in O'Connor's commentary: one of the "favourite subjects" of her pen being that "which by a somewhat misleading synecdoche, is called "women's rights" [IV, 121].)

42 Dublin Daily Express, 7 March 1882, 6.

43 Freeman's Joumal, 19 June 1882, 6.

44 See Limerick Chronicle, 7 March $1882,4$.

A HISTORICAL PERSPECTIVE ON IRISH ANTHOLOGIES 


\section{V. "REVISED AND GREATIY EXTENDED": KATHARINE TYNAN'S “CYCLOPAEDIC CABINET" (1902-3)}

Two decades after the Cabinet's first appearance, the Gresham Publishing Company, an offshoor of Blackie and Son Ltd, commissioned poet and novelist Katharine Tynan to edit a new four-volume edition of the anthology. ${ }^{45}$ In her preface, first published between 1902 and 1903 , Tynan presented the following rationale for the new volumes:

THE CABINET OF IRISH LITERATURE was first published in the early eighties, at a moment of storm and stress in Ireland, when there was little sign of the pleasant industry presently to be in the field of literature. So many have been the workers since then, and so considerable the work, that it is thought fitting that a new edition should now be issued, to include the newcomers. ${ }^{46}$

Since the publishers required that the same number of parts and volumes be retained, a sifting of the previous Cabinet was necessary. In brief, the preexisting four volumes were reduced to three, requiring numerous and telling deletions, and an all-new fourth volume was added, featuring, according to the new editor, "younger writers of the present day."

Tynan's revised edition came with a considerable editorial price - not only as a consequence of the many authors deleted, but, more significantly, as a result of the distinct narrowing of literary genres that the new editor imposed.77 Gone is the philosophical prose of William King and of John Toland (whose writing the all-accepting Read had described as well wor-

45 The Gresham Publishing Company, London, was established in 1898 largely to attend to the subscription side of Blackie's business and specialized in the "installment" trade whereby orders were taken for an entire work by "agents canvassers" and delivered by installments. In January 1898 the company had sixteen canvassing agencies in the UK: Aberdeen, Belfast, Birminghan, Bristol, Carlisle, Dublin, Edinburgh, Glasgow, Leeds, Liverpool, London, Manchester, Newcastle, Norwich, Nottingham and Swansea. The volumes were published between 1902 and 1903 , still priced at $85.6 \mathrm{~d}$. each. In contrast to the policy of selling individual numbers of the 1879-80 edition, the publishers now emphasized that orders would be accepted only for the entire work.

46 The Cabinet of Irish Literature: Selections from the Works of the Chief Poets, Orators and Prose Writers of Ireland, 4 vols. New edition by Katharine Tynan Hinkson (London: Gresham Publishing, 1902-3), i. All further page references are given in parentheses.

47 In the preface, Tynan directly states that the previous editors had included "a good many names which seemed to the present editor to belong rather to other forms of energy than to that of literature" (i).

A HISTORICAL PERSPECTIVE ON IRISH ANTHOLOGIES 
thy of preservation) "if we can overlook the theology and think only of the reasoner" (I, IOS). Scientific writings by John Tyndall, Dionysius Lardner, William Rowan Hamilton, and Richard Kirwan are now discarded, as is the work of military memoirists. As a result, this edition of the anthology excludes diverse memoirs and travel accounts by Edward Walsh, Marquis of Londonderry (on the Peninsular Wars), General Chesney, and journalist J.A. MacGahan. Also omitted are selections from orientalists William Marsden, J.L. Porter, Adam Clarke, and Thomas Keightley, although Tynan retains extracts by Richard Burton, translator of Arabian Nights. And a number of "fugitive" writers whom Read had deliberately reclaimed once again disappear-including dramatists Henry Jones, Thomas Colley Grattan, and John Crawford Wilson.

Many of Tynan's deletions appear motivated by a political and denominational bias, such as her removal of Lord Castlereagh or of the Duke of Wellington, whose speech arguing for the retention of the Lord Lieutenancy in Ireland had been included by Read. On the other hand, Tynan adds a handful of figures, such as Jonah Barrington, Arthur Geoghegan, John O'Hagan, and John Kells Ingram, who had been cited by earlier reviewers as notable omissions. Yet Tynan's narrowing of the range of genres included in the Cabinet proves decisive, most obviously in the removal of most of the oratorical writings featured in the earlier volumes. Both Read and O'Connor acknowledged the difficulty of recapturing the original power of such speeches, striving in their biographical sketches to restore at least some of the original context for this political oratory. Tynan is more sweepingly critical, refusing "to represent an illustrious name by many pages of dulness" (I, i). Her long list of excisions features speakers of many different persuasions: political orators from James Whiteside to Isaac Butt to Earl Cairns; pulpit orators William Connor Magee, William Blake Kirwan, Ulster Presbyterian Henry Cooke, as well as Fr. Theobald Mathew and Dominician preacher Thomas N. Burke.

The contracting and narrowing of literary genres that take place between the two editions of the Cabinet might usefully be analyzed in a wider literary context, specifically the influence of the contemporary "artfor-art's sake" aesthetic and its accompanying disciplinary effects. Contemporary anxieties concerning "purists" and "profiteers" also come into play, with the "profiteers" often discredited during this period, as Peter McDonald argues, "because the texts they circulate are valued for their accessibility to the greatest number, while a purist text demands the spe-

A HISTORICAL PERSPECTIVE ON IRISH ANTHOLOGIES 
cialized competence of a reading elect. ${ }^{248}$ Thus, in an uneasy self-defense, Tynan emphasizes the exigencies of a "book for popular reading," and names the exclusion of "the scholars" as her special "grief": "because their magnificent work, unless they were poets and story-tellers as well, is so difficult of representation in a book for popular reading; and one has to let them stand by dry-as-dust" (i). More specifically, for the history and evolution of Irish literature, the differences between the two editions have important implications. A comparison highlights not only the inclusiveness of Read and O'Connor's choices, but also the breadth of their understanding of what "literature" could include. Not until $199 \mathrm{r}$ and the publication of the Field Day Anthology of Irish Writing, with its commitment to the extended category of "writing," did some of the names included in the original edition of the Cabinet of Irish Literature return to circulation: many others have yet to reemerge from obscurity.

Tynan's edition also represented a significant step backward in the representation of Irish-language material, all the more striking given its publication in the midst of the Gaelic revival. Volume I of Read's edition begins with a rich range of translations of the writings of Geoffrey Keating, Michael O'Clery, and others, drawing from work by Dermod O'Connor, James Clarence Mangan, Theophilus O'Flanagan, and Read himself, as well as from Hardiman's Irish Minstrelsy. ${ }^{49}$ Later in the volume, work by John O'Neachtan and Turlough O'Carolan also appears in translation, and in one instance in the volume two poems by the eighteenth-century poet Andrew Magrath are included, untranslated, in their original Irish. Tynan, in contrast, creates a prefacing section entitled "Early Irish Writers," whose pagination in roman numerals underlines its marginality, and in which shortened biographical sketches are included without any excerpted texts. This section of sixteen writers in total forms an eclectic group, from Geoffrey Keating to Andrew Magrath, and including both Irish-language writers such as Keating, $\mathrm{O}^{\prime} \mathrm{Clery}$, Macdiare, and MacFirbis and writers in English such as Richard Stanihurst, James Usher, William Molyneux, and dramatist Ludovick Barry.

The demotion in significance of Irish-language writing from Read to Tynan appears willful, given the increased audience for and availability of such texts in the intervening years. This marginalization is even more

48 See Peter McDonald, British Literary Culture and Publishing Practice, 1880-1914 (Cambridge: Cambridge UP, 1997), 13 .

49 A significant source for Read was Thomas D'Arcy M'Gee's 'The Irish Writers of the Seventeenth Century (1846) in Duffy's Gallery of Irish Writers series.

A HISTORICAL PERSPECTIVE ON IRISH ANTHOLOGIES 
curious in view of Tynan's introductory essay to the volume; she begins with a lengthy nostalgic portmit of literature created and preserved in ancient Ireland through to the operation of the bardic schools, a profession that she contrasts sharply with the "monstrous regiment of ready writers" of the contemporary scene (xi). The essay includes further evidence of Tynan straining against her self-imposed constraints: for example, she reproduces in full a number of songs translated from the Irish, "artlessly artful things" as she calls them, regretting that "there is no place for them in the body of its Cabinet with its authenticities," yet emphasizing that "no collection of Irish poetry should be without them" (xix).

Within the anthology itself, not only was the early material severely compressed, but little if any recognition was given to newly emerging Irish-language writing. Authors such as Peter O'Leary, Agnes Farrelly or Patrick Dinneen were excluded, and translations from the Irish by Douglas Hyde appeared without their Irish originals. In sharp contrast, the American-published ten-volume anthology Irish Literature, edited by Charles Welsh, Justin McCarthy, and others and published just over a year after Tynan's anthology, devoted the last of its ten volumes to Irishlanguage literature, historical and modern. Edited by Douglas Hyde, the volume contains Irish and English versions on facing pages, with sections on "folk tales and folk songs," "prose by modern Irish authors," "poetry," and "a modern play" (Hyde's Casadh an tSugaiin). Volumes VIII and IX in this anthology also include an extensive section on "street-songs." Not unexpectedly, given the disjunction between what a 1902 reader might reasonably expect of a "cabinet of Irish literature" and what Tynan provides, the publishers, in their advertising of Tynan's edition, were at pains to point out that

[b]y Irish literature we do not here understand the legends, songs, and poems that have been preserved to us in the old Irish tongue; of that most is unknown to the people itself, though a good deal of it, in translation, will be found in this book. By Irish literature is meant the literature read and understood by the Irishmen of the present day-the expression of the ideas they really feel, of the life they truly live, in Mayo, in Limerick, in Cork and in Derry.

This passage contains many telling simplifications: between an older Irish literature and the emerging writing of the Irish-language revival, and also, in a phrase such as "the old Irish tongue" between an oral and written tradition-obfuscations still firmly lodged in some narratives of Irish literary history.

\section{A HISTORICAL PERSPECTIVE ON IRISH ANTHOLOGIES}


Tynan's particular role as "reviser" and "enlarger," rather than sole anthologist, was a genuinely difficult task; as she later explained in her memoir The Middle Years, even what she calls the "stereos" (or plates) "were to be preserved as far as possible-so that if I took out three lines on a page I had to put three lines in their place. ${ }^{50}$ However, her fourth volume, in which she had free rein, remains a significant achievement, providing a contemporary evaluation of the Literary Revival and its key writers, as they appeared in $1902 . .^{51}$ In contrast to her narrowing focus elsewhere in the anthology, in Volume IV Tynan displays an openness to contemporary writing and to women's literature. Her choice of writers ranges from Emily Lawless (who begins the volume) to Yeats, Hyde, Somerville and Ross (including two excerpts from the Real Charlotte), George Bernard Shaw (Arms and the Man), L.T. Meade, Attie O'Brien, and many others. Of ninety-one authors featured, forty-three are female-a ratio (and quality) of inclusion (from Emily Lawless to Julia Crotty) unique in the history of Irish anthologies.

Tynan's elastic definition of "Irish" (in comparison to her narrow definition of "literature") leads to the inclusion of Lionel Johnson, B.M. Croker, George Egerton, and Bram Stoker (an extract from Dracula). Oscar Wilde, however, is a conspicuous omission. In this regard, her memoir uncovers a less than easy relationship between anthologist and publisher, on the grounds of 'Tynan's interpretation of what was suitable to include:

I made a very good fourth volume in the result, but it did not please everyone. My publishers did not like my exclusion of some few writers I thought unsuited to the Irish households which would purchase the monumental work. Mr. George Moore was one of these. I said that I could not really find a suitable passage. The publishers offered me "Esther Waters" and "Sister Teresa." I was obdurate. At last I compromised on a passage from a play. Mr. Moore did not like my selection-I rather fancy there had been collaboration-and wrote me a thunderous letter about the law of copyright. I explained that he owed his inclusion to the publisher and heard no more. (2II-12)

so Katharine Tynan, The Middle Years (London: Constable, 1916), 211. Tynan also claims that she did the work in just three months, although "[a]nyone else would have taken three years or a lifetime." She acknowledges that working on the Cabinet "was the only writing thing I ever undertook over which I had moments of black despair" (2Ir).

SI Tynan's edition was reissued a number of times: in 1904, 1906 and 1908-9; however, no American edition was published.

A HISTORICAL PERSPECTTVE ON IRISH ANTHOLOGIES 
Tynan's volume ultimately featured two selections from Moore: one a scene from the third act of The Bending of the Bough (a rewriting of Edward Martyn's The Tale of the Town and on whose "collaboration" its authors quarreled bitterly) and the other, his short story "An Guina-Phósta" (The Wedding Gown"). The inclusion of Moore's story solely in its Irish-language translation seems likely to have been caused by Tynan's wrangle with Moore, and earned the story the interesting distinction of being the only Irish-language text to appear in any of her four volumes. ${ }^{52}$

In the last lines of her introduction, Tynan laments that " $[t]$ he Irish at present are a conversational, animated, unrestful race, feeling more the direct appeal of the orator or the dramatist than the quiet concentration which a book demands" (xxiv). The dilemma that such a judgment seemingly represents for an editor leads her to an extraordinarily messianic conclusion:

Perhaps, after all, our great need is of a Critic, a critic who would do immediately the sifting which is always going on behind the scenes, sifting the false from the true, the lasting from the merely perishable, in a judgment there is no gainsaying. But the Critic would be as a voice crying in the wilderness, unless he had the art to capture and to lead the opinion of the people-nay, to make an opinion in default of one ready-made. (xxiv)

Although Tynan's tone may appear excessive, her longing is not unique; one thinks for example of Eileen Battersby's recent lament in her review of $F D A$ IV-V for the "one presiding genius" who oversaw the original three volumes. ${ }^{53}$ Tynan's yearning for "the Critic" has also a disingenuous side, given the anthologist's own shaping role and power to create the modern reader. At the heart of her difficulty lies the dual character of anthologies, as both selective and representative compilations. As selections, they are always open to critique for what is excluded-the trap of all anthologies that constitutes the reviewers' foremost and recurring theme. Whereas all anthologies carry a burden of representation, that burden is especially great for collections of a national literature, in which inclusions are expected to repair previous social divisions. Hence emerge

52 For an account of the other publishing history of what Adrian Frazier describes as this "well-traveled short story," see Frazier, George Moore: $1852-1933$ (New Haven: Yale University Press, 2000), 160, and Edwin Gilcher, A Bibliography of George Moore (Dekalb: Northern Illinois University Press, 1970), 227. The Irish version was translated by "Tórna," i.e., Tadhg Ó Donnchadha, and was also published in New treland Review 16 (January 1902), 299-310, and in the 1902 collection An t. Úr. Ghort (later The Untilled Field).

53 Review of FDA IV-V, Irish Times, s October 2002.

\section{A HISTORICAL PERSPECTIVE ON IRISH ANTHOLOGIES}


not only the remedial preoccupations that underlie so many anthologies of Irish literature-from Read/O'Connor to Tynan to Deane to Bourke et al. (FDA IV \& V)-but also their large size: compensation for previous neglect and material assertion of significance. A historical perspective reveals, however, that Irish anthological representation is neither straightforward in its evolution, nor necessarily progressive in its development. Furthermore, and most pressing for the present, both historical and contemporary examples attest that as anthologies grow larger and their contents more numerous, the desire for a "judgment there is no gainsaying" deepens its conservative force. ${ }^{54}$

54 Citing the example of Vicesimus Knox's volumes Elegant Extracts; or Useful and Entertaining Pieces of Poetry... (1784), which followed speedily on an encyclopedic reprint series such as Hugh Blair's forty-four volumes of British Poets (1773-76), Price notes "how quickly information overload creates a demand for editors, even for censors-not simply to limit the data available, but to order it"; see her The Anthology and the Rise of the Novel, 77 .

A HISTORICAL PERSPECTIVE ON IRISH ANTHOLOGIES 


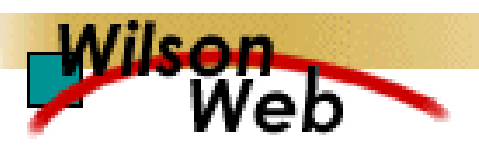

\section{COPYRIGHT INFORMATION}

TITLE: "The Cabinet of Irish Literature": a Historical Perspective on Irish Anthologies

SOURCE: Eire-Irel 38 no3/4 Fall/Wint 2003

WN: 0328804970004

The magazine publisher is the copyright holder of this article and it is reproduced with permission. Further reproduction of this article in violation of the copyright is prohibited. To contact the publisher: http://www.irishaci.org/

Copyright 1982-2003 The H.W. Wilson Company. All rights reserved. 